\title{
Research Article: Adoption regarding eco friendly technology adopted by the paddy growers to combat environmental hazards in paddy cultivation
}

口 KESHA RAM, J.K. PATEL AND GORDHAN SINGH BHATI

Article Chronicle: Received : 15.07.2015;

Revised : 05.10.2015; Accepted : 19.10.2015

KEY WoRds: Profile of paddy growers, Adoption of eco friendly technology

Author for correspondence :

\section{KESHA RAM}

Department of Extension Education, B.A. College of Agriculture, Anand Agricultural University, ANAND (GUJARAT) INDIA Email: keshavpancha199 @ gmail.com

See end of the article for authors' affiliations
SUMMARY : This study was carried out in Anand district of Gujarat state with specific objectives to study the profile of paddy growers and their adoption regarding eco friendly technology in paddy cultivation. The study revealed that more than half $(56.00 \%)$ of the paddy growers belonged to middle age group, more than two-fifth $(42.00 \%)$ of the paddy growers had primary level of education, nearly half of the respondents ( $46.66 \%$ ) had low (up to 10 years) experience, majority $(63.33 \%)$ of the paddy growers had membership in one-organization. Nearly two-fifth $(40.66 \%)$ of the paddy growers had medium size of land holding, less than one-third of the paddy growers $(30.00 \%)$ had annual income ranging from Rs. 2,00,001 to 3,00,000 lakh, more than two-fifth (41.33\%) of the paddy growers had medium level of extension contact, slightly more than half $(52.67 \%)$ of paddy growers had medium level of mass media exposure, slightly more than half $(52.00 \%)$ of the paddy growers had medium degree of economic motivation, majority ( $70.67 \%$ ) of the paddy growers had medium risk orientation. More than three- fifth $(62.00 \%)$ of paddy growers had medium level of scientific orientation, more than half (53.33 $\%)$ of the paddy growers had medium level of knowledge pertaining to eco-friendly technology, great majority $(70.00 \%)$ of the paddy growers had neutral attitude towards global warming and more than half $(53.33 \%)$ of the respondents had medium level of adoption of eco friendly technology in paddy cultivation.

How to cite this article : Ram, Kesha, Patel, J.K. and Bhati, Gordhan Singh (2015). Adoption regarding eco friendly technology adopted by the paddy growers to combat environmental hazards in paddy cultivation. Agric. Update, 10(4): 327-334. 